Donnelly, P. and Hogan, J. (2012) 'Understanding Policy Change Using A Critical Junctures Theory in Comparative Context: The Cases of Ireland and Sweden', Policy Studies Journal. 40(2): 324-50. Available: DOI: 10.1111/j.1541-0072.2012.00455.x

\title{
UNDERSTANDING POLICY CHANGE USING A CRITICAL JUNCTURES THEORY IN COMPARATIVE CONTEXT: THE CASES OF IRELAND AND SWEDEN
}

PAUL F. DONNELLY

College of Business

Dublin Institute of Technology

Aungier Street (3-062)

Dublin 2

Ireland

Email: paul.donnelly@,dit.ie
JOHN HOGAN

College of Business

Dublin Institute of Technology

Aungier Street (3-062)

Dublin 2

Ireland

E-mail: john.hogan@dit.ie 


\title{
Understanding Policy Change Using A Critical Junctures Theory in Comparative Context: The Cases of Ireland and Sweden
}

\begin{abstract}
Utilizing a new theory for examining critical junctures, we seek to better understand the nature of industrial policy change in Ireland during the 1950s and macroeconomic policy change in Sweden in the 1980s. Did these policy changes constitute critical junctures, or something less, and if so why? The theory consists of three elements - economic crisis, ideational change, and the nature of the policy change - that must be identified for us to be able to declare with some certainty if a policy change constitutes a critical juncture. Herein, we will be examining the roles of a variety of change agents including the media, central banks and politicians. Our findings will help explain why Irish industrial policy was transformed in the late 1950s, while Swedish macroeconomic policy underwent only minor change in the early 1980s.
\end{abstract}

Keywords: Crisis; critical juncture; ideas; industrial; Ireland; macroeconomic; policy change; Sweden

\section{INTRODUCTION}

The contemporary backdrop of global recession serves as our entry into how Ireland recovered from depression during the 1950s and Sweden emerged from stagnation following the oil crises of the 1970s.

By the early 1950s, the Irish economy was experiencing record emigration, a falling population and high unemployment. The protectionist policies of the 1930s were still in place, despite Western Europe experiencing rapid post war recovery. This led to questioning of extant industrial policy. By the early 1980s, the Swedish economy was in trouble despite the efforts of its right wing government. This precipitated the Socialdemokratiska Arbetarepartiet's (SAP) return to office in 1982 with a new approach to economic management. What was the nature of the policy changes in both countries at these times and what lessons might they hold for contemporary policymakers? To answer these questions, we employ a critical juncture theory.

Critical junctures are events that set processes of institutional/policy change in motion. According to the theory, a critical juncture consists of a crisis, ideational change and radical policy change (Hogan \& Doyle, 2007). A crisis can create the environment where change agents contest extant ideas and the policies based upon them. A crisis induced consolidation of a new idea - replacing an extant paradigm - leads to radical policy change. This theory contends that in the absence of 
ideational change, policy change will be of the first or second order, but not the third (radical) - the hierarchy of goals underpinning policy will remain unaltered (Hall, 1993). The theory pinpoints key events and actors crucial to policy change. Through using this theory, we are adding to our understanding of policy change.

\section{THE POLICY CHANGE LITERATURE}

Policy change is complex and must be understood in the context of societal/political change (Feldstein, 1994). Consequently, policy change has been studied from many perspectives, each of which is evolving as they borrow from one another.

The literature on incremental policy change recognizes continuity during upheavals and gradual change in times of stability that eventually becomes transformative (Thelen, 2004, p. 292). Such change occurs by the mechanisms of layering, conversion, displacement, and drift (Streeck \& Thelen, 2005, p. 19). According to this perspective, policies need to be actively maintained; otherwise, gradual change takes hold (Hacker, 2005).

The advocacy coalition framework examines coalitions sharing policy beliefs on policyoriented learning and on external events to explain policy change (Meijerink, 2005). An advocacy coalition consists of 'elected and agency officials, interest group leaders, and researchers who share a particular belief system' (Sabatier, 1988, p. 139) and form an alliance to mobilize resources to obtain greater influence in the policy-making process (Nohrstedt \& Weible, 2010, p. 16). This approach seeks to show how groups, forming over a matter of concern to them, can lead to the development of new ideas for change (Jones \& Jenkins-Smith, 2009). Recent work on advocacy coalitions 'devotes attention to the structure and evolution of belief systems, while considerations of the decision dynamics taking place inside coalitions are left aside' (Nohrstedt, 2005, p. 1042). Despite this, Mintrom and Norman (2009) have sought to incorporate the role of policy entrepreneurs in the advocacy coalition framework. 
A corollary to this approach, epistemic communities, focuses on networks of individuals sharing knowledge as they seek to achieve policy change.

According to the advocacy coalition framework, for policy change to occur, an external shock is required, such as a macroeconomic crisis (Sabatier \& Weible, 2007, p. 202). For the epistemic community approach, policy change may be triggered by uncertainty over a problem (Meijerink, 2005, p. 1063). Both approaches examine the roles of networks, ideas, information and learning processes in policy change (Haas, 2004).

Based on the concept of windows of opportunity, which arise due to exogenous shocks (Garrett \& Lange, 1995), the policy streams approach incorporates a role for policy entrepreneurs in policy change (Kingdon, 1995). For policy change to occur, when a window of opportunity forms, policy entrepreneurs attempt to gain government support for the solutions they put forward by linking problems, ideas and politics (Mintrom \& Norman, 2009). This approach has been employed in studies examining the politics of school choice, termination of public policy, and education reforms (see GevaMay, 2004; Mintrom, 2000).

Neo-institutionalism focuses on relationships between institutions and actors active within them (Mintrom \& Norman, 2009). Institutions constitute the formal/informal context that structures human behavior (Barzelay \& Gallego, 2006). In this environment, change can be difficult, requiring that actors possess a thorough understanding of their institutions. Yet, in acquiring this understanding, actors must avoid becoming part of those institutions and, thus, losing the critical perspective that would enable them to promote change (Mintrom \& Norman, 2009). The result is a limited range of policy processes, as institutions prevent change and external crises are relied upon to explain non-incremental transformation (Howlett, 2009, p. 254).

For Baumgartner, Berry, Hojnacki, Kimball, and Leech (2009) policy change is marked by long periods of stability interrupted by instances of radical change - punctuations. Policy stasis results from the inability of policy makers to mange more than a limited number of issues simultaneously, or from 
the capacity of the broader policy monopolies to dampen change (Jones \& Baumgartner, 2005). Consequently, rarely observed substantial policy alterations may occur when opponents of extant policy create new perceptions of the issue at stake and search for support for their new policy idea (Meijerink, 2005, p. 1064). Kleistra and Mayer (2001) point out that what they call 'carriers' (motors for change) and 'barriers' (hindrances to change) are two sides of the one coin. An actor could be a carrier or barrier, depending on the circumstances. Robinson (2007) predicts that this theory will become more nuanced as researchers examine the factors leading to differing degrees of stasis and punctuation in various settings.

Zittoun (2009) contends that if we want to understand policy change we must take account of what actors do to produce change. The critical junctures theory argues that a critical juncture is made up of crisis, ideational change and radical policy change, and that, within this context, policy and political entrepreneurs act as either carriers or barriers to that change (Hogan \& Doyle 2007). The theory accepts Capano's (2009) contention that stability and change are connected at the theoretical and empirical levels. Should a broad range of actors perceive the paradigm underlying extant policy as inadequate, ideational collapse will occur. However, sometimes a society re-embraces the old orthodoxy if it fails to reach consensus on a replacement (Legro, 2000). The theory presents the notion that, even in the wake of policy failure and ideational collapse, there is no guarantee a new idea will become policy. But, if the actors seeking policy change reach agreement on a replacement paradigm and gain support at a high administrative level significant policy change may follow. In this manner, the critical junctures theory addresses Mintorm and Norman's (2009, p. 650) question 'by what means can advocates of policy change come to have broad influence?'

\section{COUNTRIES SELECTED FOR EXAMINATION}

'Comparative historical analysis has a long history in the social sciences' (Mahoney \& Rueschemeyer, 2003, p. 3). Works in this area have sought to provide temporally grounded accounts of diverse topics 
including regime emergence, institutional evolution and colonialism. This approach is 'defined by a concern with causal analysis, an emphasis on process over time, and the use of systematic and contextualized comparison' (Mahoney \& Rueschemeyer, 2003, p. 3).

Lieberman (2001) argues that cross national studies of policy change, historical in context (as opposed to contemporary) and focusing on how particular policy ideas are translated into policies in specific jurisdictions, offer the prospect of conceptual breakthroughs in our understanding of policy change. By conducting such a comparative study, specifically examining policy change at the national level in two countries, we are seeking to add to the extant literature on policy change, which is made up of largely single country examinations that often juxtapose different levels of policy change (Howlett \& Cashore, 2009).

In this context of comparative historical analysis, Ireland in the late 1950s and Sweden in the early 1980 s constitute interesting cases. At these times, both countries appeared to have reached crossroads in their histories. By the 1950s, the import substitution model, employed in Ireland since the 1930s, was being questioned. The economy was stagnating and there was fear that further emigration would severely depopulate the country. The state's failure to achieve economic viability raised questions as to the value of political independence. In Sweden, in the wake of the oil crises of the 1970s, the economy was straining under the burden of supporting its substantial welfare state. With expanding budget deficits, declining competiveness and rising unemployment, there were worries that the Swedish Model of free enterprise coexisting with an expansive welfare state, extant since the late 1930s, could no longer survive. Thus, both countries at these times were experiencing great uncertainty - questioning their past decisions, but unsure of how to proceed. In a sense, they were experiencing existential anxieties: Irish nationalists had assumed that independence would bring economic prosperity, while for many Swedes the state and the welfare state had become synonymous by the early 1980s. 
In addition to having reached a crossroads in their development at these times, both countries were selected for examination using the most-similar case selection technique, where the same independent variables are focused upon (Gerring, 2007). Ireland and Sweden share the overarching criteria of being long-standing democracies and capitalist states. They have been stable democracies since the first half of the twentieth century, and were founding members of the Organisation for Economic Cooperation and Development (OECD), conditions that combine the principles of representative democracy and free market economy. Additionally, both countries are parliamentary democracies; while Sweden traditionally possesses the characteristics of a consensual democracy and Ireland the characteristics of a majoritarian democracy (Lijphart, 1999), Ireland has moved gradually towards the consensual model since the introduction of the Irish Constitution in 1937. Both countries are also on the European periphery and are relatively small in terms of population and the size of their economies. While we are examining the nature of industrial policy change in Ireland and macroeconomic policy change in Sweden (within the context of different temporal boundaries (Gerring, 2007, p. 20)), both cases constitute policy-making at the national level. Thus, the case studies' similarities ensure 'the contexts of analysis are analytically equivalent, at least to a significant degree' (Collier, 1997, p. 4).

\section{THE CRITICAL JUNCTURE THEORY}

Critical junctures, in suggesting 'the importance of focusing on formative moments,' highlight the significance of the past in explaining the present (Pierson, 1993, p. 602). There have been various approaches to studying critical junctures. For some, a critical juncture constitutes a brief period in which one direction or another is taken, while, for others, it is an extended period of reorientation.

Collier and Collier (1991), in their analysis of how Latin American countries responded to the radicalization of the working class during the early twentieth century, provide a definition of a critical juncture that can take decades to occur. For instance, they argue that the labor incorporation period was 
a critical juncture lasting nine years in Peru and 23 in Mexico. This definition fails to provide a versatile framework, or set of criteria, for determining at what point change is sufficient to constitute a critical juncture. Mahoney (2001) argues that liberal reforms during the late nineteenth/early twentieth century in Central America resulted in a series of critical junctures that lasted decades, while their consequences often endured for shorter periods. What these authors label critical junctures are more probably instances of incremental change.

In relation to short-term change, Garrett and Lange (1995) showed how electoral landslides, as in the United Kingdom (UK) in 1945, create critical junctures by producing clear mandates for policy change. Casper and Taylor (1996, p. 23) employed the concept in analyzing the liberalization of authoritarian regimes. For them, a critical juncture is a signal to potential challengers to indicate that the regime has weakened and the opportunity exists for a new political system. The critical juncture could be anything from strikes, to succession problems, to a war. Casper and Taylor (1996) show how a combination of factors in Argentina in 1982 - economic crisis, the Falklands War, and human rights violations - forced President Galtieri's resignation and prompted his successor to begin the process of democratization. Haggard (1988) examines the impact of the Great Depression on the development of the watershed Reciprocal Trade Agreement Act (RTAA), the introduction of which in 1934 allowed President Roosevelt to liberalize US trade policy and contributed significantly to today's liberal trade era. Hogan (2006) used the concept of critical junctures to examine a dramatic improvement in the Irish trade unions' relationship with government in 1987. This transformed relationship provided organized labor with a significant input into public policy formulation in Ireland over the following two decades.

Building upon Hogan and Doyle's (2007) theory that a critical juncture consists of a crisis, ideational change and radical policy change, we examine industrial policy change in Ireland and economic policy change in Sweden in three discreet stages. Each stage employs observable implications incorporating aspects of societal/political change we would expect to find if the theory holds. We evaluate each observable implication in terms of how strongly it supports the existence of a 
crisis, ideational change and radical policy change. The stronger the support, the greater the indication that a critical juncture occurred.

The theory's first stage tests for economic crisis. Much of the literature on critical junctures examines them from the perspective of crises, emphasizing the tensions that precede critical junctures. Thus, there is a longstanding debate in the literature on the relationship between crises and policy change (Haggard \& Kaufman, 1995, p. 3). A crisis implies prevailing policy cannot be sustained without deterioration (Boin, Hart, Stern, \& Sundelius, 2005). Wars, revolutions, electoral landslides, demographic changes and social movements may produce an overwhelming mandate for policy change (Greener, 2001). Economic crises were chosen for examination, as they are a more common crisis in stable democracies than wars or revolutions. An economic crisis, calling into question existing policies, can influence a variety of alternative policy preferences and trigger change - as governments, political parties and their policies are exposed to the impact of economic fluctuations (Tilly, 1975). As definitions of what constitutes economic crisis vary, we develop encompassing observable implications.

The theory's second stage tests for ideational change. New ideas, such as the growing support for a neoliberal approach to managing the struggling UK economy during the 1970s, can subsequently change the policy environment (Pemberton, 2000, p. 790). But, how ideas influence policy is complex, giving rise to questions such as: Where do ideas come from? How do they relate to failing policies? And, why does the paradigm underlying a failing policy sometimes change, resulting in policy change, whereas at other times it remains unaltered? To answer these questions, our observable implications draw on Legro (2000), who developed the concept of collapse and consolidation in the process of ideational change. The premise is that a board range of change agents perceive an extant paradigm as inadequate (collapse) and in response coalesce (consolidation) in support of an alternative idea.

The theory's third stage tests the nature of policy change through observable implications based on the work of Hall (1993), which argues that there are three orders of policy change. This enables us 
identify and differentiate policy changes ranging from adjustments, to the settings of policy instruments, to the total transformation of policy goals as happened in the UK during the late 1970s, with the shift from a Keynesian to a monetarist approach to economic policymaking.

\section{Testing for a Macroeconomic Crisis}

Scholars 'agree severe recessions make significant structural changes possible because they render politics highly fluid' (Garrett \& Lange, 1995, p. 522). However, economic crises are rare, making definition and identification difficult. This raises the question of how to identify an economic crisis. Stone $(1989$, p. 299) argues a situation does not become a problem until it is amenable to control. But, if something is controllable it must be measurable, otherwise how would we know if we are controlling it? An economic crisis must be quantifiable, and it is from quantification that identification comes.

Kaminsky, Reinhart, and Végh (2003) advocated examination of individual variables when quantifying currency crises. Pei and Adesnik (2000, pp. 138-139) developed a range of criteria for identifying macroeconomic crises (inflation above 15 percent, stagnant gross domestic product (GDP), and historians and other analysts' descriptions of significant deterioration in economic circumstances), which they note requires subjective and objective deliberations. For Garuba (2006, p. 21) and Kwon (2001, p. 105), a macroeconomic crisis can be identified through general indicators and perceptions of growth, inflation, and employment creation. We develop observable implications that build upon previous studies through combining quantitative and qualitative measures. This range of observables is used here to identify changes in nominal economic performance, as well as in perceptions of economic health. According to these observables, an economic crisis may be indicated by:

01. Stagnant or negative GDP growth (Pei \& Adesnik, 2000).

O2. Unemployment above 10 percent (Pei \& Adesnik, 2000).

O3. Inflation and interest rates above 10 percent (Pei \& Adesnik, 2000).

O4. National debt, as a percentage of GDP, increasing at more than 10 percent, annually.

05. The level of economic openness declining.

O6. Public perceives an economic crisis.

O7. National/international media perceive an economic crisis. 
O8. Economic/political commentators perceive an economic crisis.

O9. Central bank perceives an economic crisis.

010. Organisation for Economic Cooperation and Development (OECD) perceives an economic crisis.

011. Elected representatives perceive an economic crisis.

012. Government pronouncements on economy consistent with a crisis management approach.

\section{Testing for Ideational Change}

Although economic crises can have great impact, they will not determine policy, whose formulation is 'centered in domestic political and ideational processes' (Golob, 2003, p. 75). Policies can be discredited due to their implication in, or inability to resolve, a crisis. When a policy is in difficulty, windows of opportunity appear, wherein change agents contest the viability of the prevailing paradigm (Kingdon, 1995). 'Ideas facilitate the reduction of ... barriers by acting as coalition-building resources among agents who attempt to resolve the crisis' (Blyth, 2002, p. 37). Significant policy change depends upon actors reaching consensus upon, and consolidating around, new ideas (Hogan \& Doyle, 2007). Ideas determine the path of subsequent policy, as policymakers work within a framework of ideas and standards that specify not only the goals of policy, but also the instruments to be used to achieve these goals (Hall, 1993, p. 279). The greater the consensus encompassing an idea, the more protected the policies derived from it. Ideas are the mechanisms of change in critical junctures (Golob, 2003). Therefore, ideational change stands between a crisis and policy change.

Hogan and Doyle (2007) contend ideas are introduced into the policy domain by three groups of change agents. The first are outside influencers, e.g., media, OECD, International Monetary Fund, World Bank and consumer groups. The second group is Kingdon's (1995, pp. 179-183) 'policy entrepreneurs', who may be civil servants, technocrats, academics, economists and interest groups who engage in policy innovation. Policy entrepreneurs challenge existing paradigms and vie for the attention of politicians to get their ideas into the policy-making environment (Kingdon, 1995). Policy entrepreneurs, acting as change agents, are essential in generating, and advocating, new policy ideas to 
replace extant and failing arrangements. However, the most important change agents are what Dahl (1961) termed 'political entrepreneurs', by which we mean elected politicians. Political entrepreneurs 'exploit moments of instability' and 'invest resources in the creation of a new policy, a new agency, or new forms of collective action' (Sheingate, 2003, pp. 188-190). In a crisis, a political leader, usually an opposition leader, will seek new policy ideas to rectify the ills of an existing paradigm. Policy entrepreneurs and outside influences are responsible for producing these ideas. The political entrepreneur picks and chooses from the policy ideas put forward, and then acts as a figurehead, introducing the chosen ideas into the policy-making process. We see political entrepreneurs as the bridge between those advocating new policy ideas (policy entrepreneurs) and the political institutions implementing them. As such, political entrepreneurs shape the terms of political debate by influencing agendas (Hwang \& Powell, 2005, p. 212). 'Successful political entrepreneurs are able to consolidate innovations, producing political or social change that has enduring effects in the form of new programs, policies, or organizations' (Hwang \& Powell, 2005, p. 214). Thus, the triumph of a new idea depends upon its promotion and adoption by change agents (Oliver \& Pemberton, 2004).

INSERT FIGURE 1 HERE

According to Legro's (2000, p. 419) two-stage model of ideational change, if agents agree the existing paradigm is deficient and should be replaced, the first stage - ideational collapse - has occurred. Below are the observables that indicate ideational collapse:

013. Media question efficacy of the current model and/or specific policy areas.

014. Opposition parties critique the current model and propose alternative ideas - at election time their platform will be built around these alternatives.

015. Civil servants, technocrats, academics, economists (policy entrepreneurs) critique the current model and propose alternatives.

016. Civil society organizations, e.g., labor unions, employer organizations, consumer groups (policy entrepreneurs), critique the current model, reflecting Hall's (1993) coalitioncentered approach.

017. Widespread public dissatisfaction with the current paradigm, observable through opinion polls, protests, etc. 
O18. External/international organizations (policy entrepreneurs) critique the current model and/or actively disseminate alternative ideas.

These observables suggest that as agents debate the viability of the old model, they generate solutions to its ills through new ideas. However, 'even when ideational collapse occurs, failure to reach consensus on a replacement could still produce continuity, as society reflexively re-embraces the old orthodoxy' (Legro, 2000, p. 424).

If consensus is achieved, it marks the second stage of Legro's model - agents coordinating a replacement set of ideas to the dominant creed. Political entrepreneurs consolidate innovations by combining interests to produce winning coalitions (Sheingate, 2003, pp. 192-193). This is similar to Baumgartner and Jones' (1993) notion of policy images, where the public's understanding of a problem is used by policy entrepreneurs to explain how policies become linked to problems. These observables indicate new ideational consolidation:

019. A clear set of alternative ideas, developed by policy entrepreneurs.

O20. A political entrepreneur injecting new ideas into the policy arena.

O21. The political entrepreneur combines interests, including policy entrepreneurs, to produce consensus around a replacement paradigm.

\section{Testing for Policy Change}

Following political entrepreneur-led consolidation around a new idea (ideational change), the theory leads us to expect significant policy change. The observable implications here are based upon Hall's (1993) concepts of first, second and third order change. A first order policy change involves alteration to the settings of policy instruments - such as increasing emission requirements for automobiles; a second order change sees alteration to the instruments of policy - such as changing from an administered emission standard to an emission tax; and a third order policy change sees the goals of policy changing - such as the shift to ex ante preventative product design and away from ex post regulations (Howlett, 2007, p. 53). For third order policy change, Hall (1993, p. 291) argues exogenous shocks, and policy failures, discredit extant paradigms, leading to re-examination of the belief systems through which policy was created - a paradigmatic change. 
The observables below enable us identify, and differentiate, normal and fundamental shifts in policy. They incorporate swift and enduring change. As we are dealing with the concept of a critical juncture (radical change), we assume this is not a long process; otherwise, it would be incremental change. Also, if the change is to endure in an environment full of competing policy entrepreneurs and ideas, it should survive a change of government. By selecting a period exceeding a government's term of office, we are addressing the problem in policy dynamics of defining and operationalizing the scope and timing of policy change (Howlett, 2009). Clarifying when a policy change can be regarded as fundamental, and the length of time it takes to observe such a change, is usually based on a multi-year perspective to identify actual, as opposed to temporary, policy alterations (Capano \& Howlett, 2009). Thus, if

022. Policy instrument settings changed (swiftly and for longer than one government's term of office),

O23. The instruments of policy changed (swiftly and for longer than one government's term of office), and

024. The goals behind policy changed (swiftly and for longer than one government's term of office),

there may have been a radical change in policy.

The data for each observable implication was evaluated independently by each author and assigned a score according to whether it indicated strong (3), medium (2), weak (1) or no support (0) for that observable. This allowed for an overall evaluation as to whether there was strong, medium, weak or no support for crisis, ideational collapse, new ideational consolidation and third order policy change in respect of Irish industrial policy and Swedish macroeconomic policy. The stronger the support, the more the findings indicate that a critical juncture occurred. In employing this coding approach, designed to arrange data into classes permitting comparisons between items in the same category (Maxwell, 2005, p. 96), we are allowing for a more nuanced understanding of what constitutes a critical juncture. As interpretation plays a part in divining meaning from codes, reporting of findings involves thick description of the categories and contexts (Polgar \& Thomas, 2008, p. 248). This 
approach also allows for the calculation of inter-coder agreement: percentage agreement above 91 per cent; and Krippendorff alphas above 0.8, which Krippendorff (2004, p. 241) deems reliable beyond chance (see Appendix).

\section{IDENTIFICATION OF MACROECONOMIC CRISIS}

\section{The Irish Economy in the 1950s}

Ireland is interesting to examine, as it is often ignored in comparative policy change studies. After independence in 1922, the Cumann na nGaedhael government employed a free trade policy, centered on agriculture. However, after Fianna Fáil came to power in 1932, during the Great Depression, economic policy focused on protectionism. While protectionism was introduced in many countries at the time, Irish protectionism was also driven by isolationist factors related to the country's colonial history. For Ireland, the benefits of protectionism - meager industrial expansion - had been reaped by the 1940s. From then on, the economy stagnated, as industry was supplying as much of the domestic market as it could (Hillery, 1980, p. 46).

\section{INSERT TABLE 1 HERE}

From Table 1, we can see that between 1951 and 1958, GDP rose by less than 1 percent per year. The debt to gross national product (GNP) ratio increased between 1951 and 1959, but by less than 10 percent per annum, while the level of economic openness reached a decade-long low in 1959, having fallen by over 24 percent after 1951. Overall, employment declined by 12 percent during the 1950s, with the unemployment rate peaking at 9.6 percent in 1953 . The reason unemployment did not surpass 10 percent was due to the high level of emigration; half a million people left the country in search of work during this decade, with the result that the population fell to its lowest level since the first half of the $18^{\text {th }}$ century (Haughton, 1995). Inflation surpassed 10 percent at the start of the 1950s, before transforming into deflation in 1959, while interest rates remained relatively low. The main 
economic indicators were clearly in disequilibrium. Unfortunately, opinion polls were not carried out in Ireland until the 1960s.

Accounts in the national and foreign media, typical of the time, perceived the Irish economy to be in crisis. The Irish Independent (1959a, p. 4) argued the economy's foundations were in need of repair. While writing in its main rival, The Irish Times, FitzGerald (1959, p. 5) argued that, if the population continued to fall, there was a danger the state could be reduced to both political and economic insignificance. Time International (1958, p. 44) remarked there had been few economic advances for Ireland during the 1950s, while The Economist (1959, p. 15) concluded that most indicators of economic performance were dire. By mid 1958, the Irish Independent (1958a, p. 11) argued economic isolation was impractical.

The OECD (1961, p. 5) and Central Bank of Ireland (1961, p. 5) regarded the economy as depressed. Agricultural production was abnormally low, industrial output was faltering and there was a large trade deficit (Central Bank of Ireland, 1957, p. 27). In a damning indictment, the Central Bank (1957, p. 34) observed 'the present economic and financial situation scarcely justifies the retention of confidence in large-scale expenditure on public works and social amenities as a means of stimulating useful economic activity'. This report spoke of the dangers of insolvency and the loss of economic sovereignty.

Ó Gráda and O’Rourke (1995, p. 214) argue that, 'in the 1950s, Ireland's relative [economic] performance was disastrous'. In 1957, manufacturing output was no higher than in 1953, while building activity was stagnant (OEEC, 1958, p. 15). As Lyons (1973, p. 618) notes:

A serious crisis of confidence developed, caused by widespread anxiety that the performance of the economy was so poor the country was falling behind Western European standards, not only in productivity, but in the social benefits productivity might be expected to confer.

Commentators were unanimous in their condemnation of economic performance. 
Politicians from across the political spectrum now 'realised that the Irish economy could not survive in isolation' (Murphy, 1997, p. 57). Daniel Desmond, of the Labour Party, argued that it was time for the political establishment to realize that solving the problems with the economy superseded their power struggles (Irish Independent, 1959b, p. 9). As Tánaiste, ${ }^{1}$ Fianna Fáil's Seán Lemass commented on the need to develop a viable economy, ${ }^{2}$ adding, when he became Taoiseach ${ }^{3}$, that the task for the generation of the 1950s was to 'consolidate the economic foundations of our political independence' (The Irish Times, 1959a, p. 8). While opposition parties might be expected to criticize the economy, when the government agrees with their evaluations normal politics has been suspended.

\section{The Swedish Economy in the Early 1980s}

Following the first oil crisis, the Swedish government's expenditure outpaced revenues. Although among the world's richest countries, Sweden strained under the burden of supporting its welfare state (Time International, 1976, p. 8). Budget deficits were financed through borrowing. However, the nonsocialist coalition governments (1976-1982) wanted neither to raise taxes nor be accused of dismantling the welfare state (Bryon \& Branegan, 1982, p. 32).

\section{INSERT TABLE 2 HERE}

From Table 2, we see that, by 1982, Sweden's main economic indicators pointed to stagnation, with GDP growth contracting in both 1977 and again in 1981. The debt to GNP ratio stood at 59.3 percent, having grown by 250 percent in the six years to 1982 . Budget deficits accelerated during the late 1970s and, by 1982, reached 13 percent of GNP, five times their 1976 level (Osnos, 1982, p. A15). 'The budget deficit and the swing in the budget balance since the mid-1970s has been more pronounced than in most other OECD countries' (OECD, 1982, p. 16). Both inflation and interest rates were regularly above 10 percent in the half decade to 1982, while unemployment reached 3.1 percent, its

\footnotetext{
${ }^{1}$ Tánaiste $=($ Gaelic: 'heir to the chief') Deputy Prime Minister

${ }^{2}$ Dáil Éireann Debates, 28 April, 1959, Vol.174, Col.1122.

${ }^{3}$ Taoiseach $=$ (Gaelic: 'chief') Prime Minister.
} 
highest since 1945 - a political scandal in a country accustomed to full employment (Apple Jr., 1982a, p. 3). However, some economists believed unemployment was closer to 16 percent if the figure included jobless in training programs, workers forced into early retirement, and those who had ceased looking for work (Bryon \& Branegan, 1982, p. 32). Economic openness dipped during the late 1970s, before recovering in the early 1980 s.

According to The New York Times, Sweden 'now suffers from low growth, falling industrial output and an unfavourable trade balance' (Apple Jr., 1982b, p. 17). The Financial Times said Swedes were nervous about the future, and reluctant to see their welfare state cut back (Dullforce, 1982a, p. 15). 'The welfare state is in a crisis of legitimacy,' observed Hans Vetterberg, Sweden's leading opinion analyst (Osnos, 1982, p. A15). This is indicative of the wider media consensus on Sweden's problems.

The public sector outgrew private industry after 1978, with the result that productivity growth declined (OECD, 1992, p. 62). Ironically, this happened under a non-socialist government and, by 1982, public sector expenditure constituted 67 percent of GNP (OECD, 1990, p. 59). Wages exploded in a self-destructive series of agreements that placed Swedish firms in the un-competitive position of having the highest paid workforce in the world (Ahlén, 1989). Sweden's share of the world economy dropped by 40 percent during the 1970s and its exports stagnated (Ryden \& Bergstrom, 1982). By the 1980s, the Swedish economy, once the envy of Europe, had been hobbled (Apple Jr., 1982a, p. 3).

INSERT TABLE 3 HERE

From Table 3, we can see that more than two thirds of all available observable implications strongly support the argument that Ireland, in the late 1950s, experienced an economic crisis. In the case of Sweden, seven observables provide strong support for an economic crisis in the early 1980s, with three providing medium support and two weak. While more observables pointed more strongly to an economic crisis in Ireland than in Sweden, overall, both sets of findings show two economies in 
serious difficulty. The next section examines both countries for ideational change and if policy change followed this.

\section{IDENTIFICATION OF IDEATIONAL AND POLICY CHANGE}

\section{The Ideas Underlying Irish Industrial Policy}

Economic stagnation led to questioning of protectionism among civil society groups and the media (O’Day, 2000, p. 27). The Federation of Irish Manufacturers (FIM) called for an investigation of a free trade regime (Irish Independent, 1958b, p. 10), with the debate influenced by the United States (US); 'Ireland participated in the Marshall Plan, to raise money for development programs', and in return the US pressed it to 'introduce unilateral reforms to encourage exports and foreign investment' $(\mathrm{O}$ 'Hearn, 1998, p. 39). As we shall see, during the 1950s, these reforms were gradually implemented, not on account of US pressure, as O'Hearn (1998) contends, but due to economic crisis. By the late 1940s, in the context of the General Agreement on Tariffs and Trade (GATT) and the European Coal and Steel Community (ECSC), protectionism was being dismantled.

The Industrial Development Authority (IDA), established in 1949 to encourage indigenous industries, initially opposed Ireland's participation in the general liberalization of trade in Europe. However, experience was to alter the IDA's attitude and it began to act as a 'policy entrepreneur', recognizing that 'export-led industrialization was the only way to develop the Irish economy and foreign investment as a source for such industrialization’ (Donnelly, 2007, p. 144). Córas Tráchtála Teoranta (CTT, the Irish Trade Company) was established to promote exports to North America. The Finance Act of 1956 was designed to encourage exports, whether by Irish companies or foreign companies based in Ireland. However, the policy changes prior to 1957 were essentially last-ditch attempts to maintain protectionism. The government stretched extant policy to incorporate aspects of attracting foreign direct investment (FDI) and encouraging exports. 
The alterations to protectionism contradicted its intellectual coherence. The protectionist policy matrix, consisting of a range of legislation (the Control of Manufactures Acts, special import levies and customs duties), was fraying (Donnelly, 2007, pp. 149-150). Lynch (1959, p. 7) argued the old economic policies had failed and closer economic cooperation with Britain was not at variance with independence. Consequently, '1957 is conventionally thought of as the end of an era, marking the final exhaustion of the ideas of the first generation of political leaders' (Garvin, 1982, p. 37).

Contestation of the orthodoxy underlying industrial policy, by agents agreed on its inadequacy, resulted in its collapse. Fianna Fáil contested the 1957 election attacking the economic model it had created. Lemass argued that increased employment would come from exports generated by attracting foreign capital and through tax exemptions (The Irish Times, 1957a, p. 1). Fianna Fáil won the election due to the state of the economy (The Irish Times, 1957b, p. 9). Lemass became Minister for Industry and Commerce and 'on his return to office began the process of opening the state to foreign investment' (Girvin, 1994, p. 125), a process tentatively in motion under the predecessor coalitiongovernment (Donnelly, 2007, p. 140ff).

Lemass, who had once championed protectionism, was influenced by the ideas of T.K. Whitaker, Secretary of the Department of Finance, as set out in Economic Development (Department of Finance, 1958a). Whitaker was committed to export-led growth, as he recognized extant policies had failed (Lee, 1989, p. 343). In Economic Development, he advocated more planning, fewer tariff barriers and an emphasis on productive investment. This document marked the culmination of activism within higher echelons of the civil service (Murphy, 1997).

Lemass assumed the role of a political entrepreneur, championing economic openness. His previous role as an advocate of protectionism, and his conversion to economic openness, places him outside the realm of change agents Skocpol (1979) examined. He was not a political actor untainted by old failures, but came to advocate new ideas to rectify problems created by those failures. 
There followed a reappraisal of the policies pursued since the 1930s. Few politicians, either in government or opposition, as well as the media, took notice of Economic Development upon publication (Murphy, 2005, p. 32); its significance was recognized only by the entrepreneurial network (Whitaker and his colleagues within the Department of Finance) that fostered it and the political entrepreneur who championed it.

Economic Development proposed a transition to free trade, stimulation of private investment, the introduction of grants and tax concessions to encourage export manufacturing, and the inducement of direct investment by foreign, export-oriented manufacturers. Economic Development was the genesis of a new paradigm with which to manage the economy and formed the backbone of the 1958 White Paper First Programme for Economic Expansion (Department of Finance, 1958b), which established a coherent set of ideas based on an outward-looking strategy (Horgan, 1997).

Lemass succeeded De Valera as Taoiseach in 1959. The ideas propagated by Lemass and Whitaker persuaded the opposition parties to coalesce around them. It was clear in mid 1959 that academia and representatives of the leading interest groups were rowing in behind Economic Development (The Irish Times, 1959b, p. 9). Lemass possessed the mandate and opportunity to inject new ideas into the policy arena.

There was ideational collapse as change agents critiqued protectionism. Whitaker, and the Department of Finance, constituted policy entrepreneurs, while other change agents (the media, trade unions and farmers organizations) supported the ideas in Economic Development. Lemass was the political entrepreneur they rallied around, as he championed their reform plans. That he was a senior politician fits with the argument that change is more likely if the political entrepreneur commands significant resources (Campbell, 2004).

\section{Changes in Irish Industrial Policy}

Under the coalition government (1954-57), tax breaks and grants had been provided to foreign firms setting up in Ireland. During the latter stages of the protectionist period, the organizations established in 
the early 1950s as part of the protectionist matrix (IDA, CTT) came to support an outward-looking, and increasingly active, industrial policy. The coalition-government, through extending the remit of the IDA, began encouraging foreign investment to fill gaps left by indigenous industry. But, to regard these policy changes as a break with protectionism would be incorrect; they were a form of institutional layering. The overarching protectionist policy endured. These moves represent learning effects, an effort to make protectionism work (Donnelly, 2007, pp. 150-1). At most, the policy decisions up to 1957 constituted second order changes. However, the inefficiencies of the protectionist path were immune to incremental change.

Subsequently, under Lemass, an outward-orientated strategy became the bedrock of industrial policy. The Industrial Development (Encouragement of External Investment) Act of 1958 brought an easing of restrictions on foreign ownership of industry. This, aligned with the increase in the value of tax breaks, represented an unambiguous signal of the government's intention to facilitate foreign participation in export-orientated industrial development. During the debate on this Act, Lemass pointed out that industrial policy had moved from focusing on import-substitution and indigenous industry to encouraging exports and FDI. ${ }^{4}$ This shift in policy required a significant investment of political capital.

The First Programme for Economic Expansion (Department of Finance, 1958b) concluded that the state should provide facilities to encourage industrial development and welcome FDI. The creation of the European Economic Community (EEC) in 1957 informed ideas on how industrial expansion could be stimulated. Industrial development would have to target export-orientated projects that would perform well in open competition. The government, its focus on exports and FDI, regarded protectionism as untenable.

Ireland subsequently pursued an increasingly liberal trade policy. Increasing levels of resources were devoted to the IDA to attract FDI and membership of the EEC became the objective of this

\footnotetext{
${ }^{4}$ Dáil Éireann Debates, 20 February, 1958, Vol.165, Col.533.
} 
transformed policy paradigm. Significantly, the Second Programme for Economic Expansion (Department of Finance, 1963, 1964) signaled the repeal of the protectionist Control of Manufacturers Acts on the grounds that foreign investment supported indigenous efforts to grow the economy and create jobs. The collective mindset had disengaged from protectionism - constituting a third order policy change.

\section{The Ideas Underlying Swedish Macroeconomic Policy}

Although right wing parties formed a number of governments between 1976 and 1982, they remained divided on many issues; consequently, the coalition could not agree on how to counteract the deteriorating economic situation (Peterson, 1987, p. 33). In spring 1981, the non-socialist coalition government and the opposition SAP reached agreement on reducing marginal taxation. However, this led to a dispute within the already fractured coalition that saw the Moderates resign from government. Prime Minister Thorbjörn Fälldin then formed a minority government of the two middle parties (Center and Liberal) that held only 102 of the 350 seats in the Swedish Parliament, the Riksdag. Ironically, the right wing administrations nationalized and subsidized weak industries, something the SAP had resisted during its decades in power (OECD, 1978, p. 21). The problem was the public sector took up spare labor in a recession, but did not shed it during economic expansion.

In autumn 1981, the krona was devalued by 10 percent and the following spring the nonsocialist coalition introduced an austerity program. The government hoped its attempts to combat the economy's problems would generate respect for non-socialist policies. The reductions in pensions, sick pay and subsidies for food, to slow the growing deficit, alienated an electorate already burdened with taxes (Time International, 1982, p. 23).

The 1982 election was regarded as determining whether public opinion had shifted away from social democracy. Although the ideas underlying extant policy might have collapsed, the debates failed to generate a coherent set of alternative ideas. That said, policy entrepreneurs, such as the Centre for Business and Policy Studies (SNS) and Timbro (a free market think tank), both created by the Swedish 
Employers' Federation (Svenska Arbetsgivarforening (SAF)), were disseminating monetarist ideas (Blyth, 2002, pp. 214-15). However, no political entrepreneur emerged during this period of ideational contestation to champion these alternative ideas, as no politician, for fear of electoral suicide, was willing to propose abandonment of the welfare state. The failure of change agents to cluster around a new economic ideational paradigm means societal actors invariably re-embrace the existing orthodoxy (Legro, 2000).

During the election campaign, the SAP, under the leadership of Olof Palme, attacked the viability of another non-socialist government. However, nearly all economic ideas presented were variations on existing themes. The SAP won the election on a series of proposals to correct existing economic arrangements and by exploiting voters' fears over rising unemployment and their disenchantment with the policies of the outgoing government (Time International, 1982, p. 23). In lieu of alternatives, society reflexively re-embraced the ideas underpinning the welfare state. With Olof Palme's return, traditional socialist policies went to the top of the agenda, albeit in altered form.

\section{Change in Swedish Macroeconomic Policy}

The SAP's recovery program - the Third Way - argued growth required redistribution of income from labor to capital (Apple Jr., 1982a, p. 3). This marked a change in SAP planning, an attempt to maintain a level of social democracy and to demonstrate the SAP's capacity to revitalize the economy (Meidner, 1989). The subsequent public sector cuts and restraint in wage negotiations resulted in disagreement between the SAP and the Landsorganisationen $i$ Sverige (LO) - the largest trade union association (Andersson, 2006, p. 116). Palme, rejecting the non-socialist's approach of squeezing inflation out of the economy at the cost of higher unemployment, intended to keep people in employment by paying them less, giving industry a cost advantage.

The Third Way was a wide-ranging stabilization program encompassing demand management measures, as well as initiatives to ensure an equitable distribution of the burden of adjustment (OECD, 1984, p. 21). The SAP was determined to pour funds into job-creating industries and to increase taxes 
for that purpose (Apple Jr., 1982a, p. 3). The centerpiece of Finance Minister Kjell-Olof Feldt's 'crisis plan' to stimulate the economy was devaluation of the krona by 16 percent, implemented in conjunction with a price freeze and increases in sales and corporate taxes (Dullforce, 1982b, p. 1).

The objective was to achieve export-led, investment-driven, recovery (OECD, 1984, p. 21). The devaluation and international economic recovery resulted in high earnings and export expansion (Ahlén, 1989, p. 333). The thrust of SAP policies pointed in a different direction than previously, with Feldt prioritizing private sector growth, profits and market forces. A series of structural reforms were introduced overturning traditional SAP priorities. Fiscal policy was held tight and the slimming of the public sector would, it was argued, create crowding in effects (Mjoset, 1992, p. 349).

To placate the LO, the SAP, in the face of SAF opposition, introduced wage-earner funds. In 1976, the LO proposed a levy on corporate profits be used to transfer control of enterprises with more than 50 employees to the unions (Whyman \& Burkitt, 1993, p. 612). However, the version implemented was modified 'from an overtly socialist union proposal to a number of toothless share holding funds' that dissatisfied the LO (Meidner, 1993, p. 223). The Third Way marked a reversal of the SAP's perspective on social policy, moving from an emphasis on investment in growth to an emphasis on cost reduction (Andersson, 2006, p. 124).

Despite social democracy's failures, Swedish society was reluctant to abandon this model. The SAP reasserted its commitment to the Swedish model's precepts of an active role for government by stimulating economic growth and maintaining full employment (Walters, 1987, p. 74). The SAP's Third Way strategy, while damaging its relationship with the unions, contributed to economic expansion in conjunction with an international economic recovery. As we can see from Table 2 , levels of unemployment, inflation and national debt fell after 1982, while levels of economic growth and openness were reasonable.

Ideational collapse, in the wake of economic crisis, provided a window of opportunity for the SAP to implement new economic policies. However, change agents did not consolidate around a 
replacement economic orthodoxy. Consequently, the ideas underpinning the policies of the welfare state endured.

\section{INSERT TABLE 4 HERE}

In Table 4, we see that in Ireland, during the late 1950s, the observable implications strongly support the belief that the ideas underpinning industrial policy, focused on protectionism, collapsed. Change agents, led by Whitaker, put forward alternative ideas. Lemass, acting as a political entrepreneur, championed these ideas in the policy-making environment, around which change agent consensus developed, leading to their consolidation. These new ideas involved opening the economy and pursuing FDI. The observables strongly support the argument that the new policies implemented by Lemass altered the setting, instruments and hierarchy of goals behind industrial policy - a third order policy change. This change in industrial policy, preceded by macroeconomic crisis and ideational change, constituted a critical juncture.

The observables provide only medium support for ideational collapse in Sweden in the early 1980s and show that change agents failed to consolidate around a replacement orthodoxy to social democracy. No political entrepreneur emerged willing to champion alternative ideas to those underlying economic thinking since the 1930s. To move from the welfare state would have broken with 50 years of policy tradition, whereas in Ireland to abandon protectionism meant breaking with a policy tradition of only half as long. The observables indicate there was no critical juncture in Swedish macroeconomic policy, the only policy changes being of the first order.

\section{CONCLUSION}

This paper sought to provide a better understanding of policy change by using critical junctures theory to examine changes in Irish industrial policy in the 1950s and Swedish macroeconomic policy in the 
early 1980s. According to the theory, a critical juncture consists of crisis, ideational change and radical policy change, with ideational change linking crisis and policy change.

Employing a range of observable implications, we found a critical juncture in Irish industrial policy in the 1950s. In the midst of a macroeconomic crisis, the protectionist policy, having been undermined by previous failures, was overcome by change agents, led by a political entrepreneur, in the form of Seán Lemass, consolidating around ideas of economic openness. There followed a third order change in industrial policy. However, in Sweden there was no critical juncture in macroeconomic policy in the early 1980s. Although the economy was in crisis, and this was undermining confidence in prevailing economic orthodoxy, neither the non-socialist parties, or the SAP, were willing to challenge this. While ideational collapse occurred, a political entrepreneur willing to champion a new set of ideas on economic management failed to emerge and there was only a first order policy change.

In Ireland, since the late 1950s, the outward orientated industrial policy has remained unaltered due to recognition that protectionism did not work and that a large number of jobs and a high percentage of FDI depend upon membership of the European Union (EU). The economic crisis of the 1980s, as well as the current crisis, did not provoke a rethinking of this policy. During the current economic crisis, the export sector is one of the few success stories in an otherwise dismal picture (The Irish Times, 2011) and negotiations over the country's bail-out saw a key element of industrial policy, the 12.5 percent corporation tax rate, asserted as non-negotiable in the face of Franco-German pressure (Deegan, 2011).

In Sweden, moving away from social democratic values to maintain social democracy was the SAP's approach in the early 1980s. At the time, with neoliberalism on the rise, social democracy was seen as swimming against the tide. Now, 30 years later, a large question hangs over the future of the neoliberal project. Its logic is being stretched through the socialization of banks' enormous losses. Consequently, we are likely to witness neoliberalism's underlying thinking coming under increasing scrutiny. 
The critical junctures theory can make a significant contribution to the study of policy change. Unlike arguments suggesting the core attributes of policy will only change when the advocacy coalition that instituted the policy is removed from power, the critical junctures theory argues that, irrespective of who is in power, as in Ireland in 1959, policy changes of the most dramatic kind can occur. The approach incorporates windows of opportunity presented by crises/policy failures, epistemic communities, and carriers and barriers to policy change in the form of policy and political entrepreneurs. Unlike neo-institutionalist approaches, critical junctures is designed to examine and account for policy change or its absence, and like incrementalist approaches, but unlike the punctuated equilibrium model, it can account for less than dramatic policy changes - as in Sweden in 1982. The critical junctures theory argues significant policy change depends upon actors reaching consensus upon, and consolidating around, new ideas. The presence or absence of ideational change differentiates between crises followed by radical policy changes and those followed by policy changes of a less dramatic nature.

The theory shows how established policies are protected by the coherence of their underpinning ideas. However, when these ideas are undermined by crisis, the extant paradigm can be stretched to incorporate elements of other paradigms to ensure the policy's survival. But, if stretched too far, the extant paradigm's logic collapses. Political entrepreneur-led consolidation around a new set of ideas was the difference between an economic crisis that led to the critical juncture in Irish industrial policy, and one that did not lead to a critical juncture in Swedish economic policy. Different network configurations are associated with different orders of policy change (Pemberton, 2000, p. 771).

The theory is capable of analyzing various policy change issues, and the nature of that change. With minor modifications, the observables could be used to examine policy change in, for example, defense policy, foreign policy, health policy, gender mainstreaming or education policy. However, a limitation to the approach set out here is its subjectivity. Our hope is that other researchers will perfect 
what we have done, endowing the approach with greater rigor to ensure greater confidence in its findings.

\section{REFERENCES}

Ahlén, Kristina. 1989. "Swedish Collective Bargaining Under Pressure: Inter-union Rivalry and Incomes Policies.” British Journal of Industrial Relations 23 (3): 330-46.

Andersson, Jenny. 2006. Between Growth and Security: Swedish Social Democracy from a Strong Society to a Third Way. Manchester: Manchester University Press.

Apple Jr., Raymond W. 1982a. "For Palme, Some Thorns on the Roses." The New York Times (21 September): A3.

-----. 1982b. “Social Democrats Favored in Sweden.” The New York Times (18 September): 17.

Barzelay, Michael, and Raquel Gallego. 2006. "From 'New Institutionalism' to 'Institutional Processualism': Advancing Knowledge about Public Management Policy Change.” Governance 19 (4): 531-57.

Baumgartner, Frank R., Jeffrey M. Berry, Marie Hojnacki, David C. Kimball, and Beth L. Leech. 2009. Lobbying and Policy Change: Who Wins, Who Loses, and Why. Chicago, IL: University of Chicago Press.

-----, and Bryan D. Jones. 1993. Agendas and Instability in American Politics. Chicago, IL: University of Chicago Press.

Blyth, Mark. 2002. Great Transformations: Economic Ideas and Institutional Change in the Twentieth Century. Cambridge: Cambridge University Press.

Boin, Arjen, Paul 't Hart, Eric Stern, and Bengt Sundelius. 2005. The Politics of Crisis Management: Public Leadership Under Pressure. Cambridge: Cambridge University Press.

Bryon, Christopher, and Jay Branegan. 1982. "Why Bankers Have the Jitters." Time International (20 September): 32.

Campbell, John L. 2004. Institutional Change and Globalization. Princeton, NJ: Princeton University Press.

Capano, Gilberto. 2009. "Understanding Policy Change as an Epistemological and Theoretical Problem.” Journal of Comparative Policy Analysis: Research and Practice 11 (1): 7-31.

-----, and Michael Howlett. 2009. "Introduction: The Determinants of Policy Change: Advancing the Debate." Journal of Comparative Policy Analysis 11 (1): 1-5.

Casper, Gretchen, and Michelle M. Taylor. 1996. Negotiating Democracy: Transitions from Authoritarian Rule. Pittsburgh, PA: University of Pittsburgh Press. 
Central Bank of Ireland. 1957. Annual Report. Dublin: Stationery Office.

-----. 1961. Annual Report. Dublin: Stationery Office.

Collier, David. 1997. "Comparative Method in the 1990s." APSA-CP: Newsletter of the APSA Organised Section in Comparative Politics 9 (1): 1-5.

Collier, Ruth B., and David Collier. 1991. Shaping the Political Arena: Critical Junctures, the Labor Movement, and Regime Dynamics in Latin America. Princeton, NJ: Princeton University Press.

Dahl, Robert. 1961. Who Governs? Democracy and Power in an American City. New Haven, CT: Yale University Press.

Deegan, Gordon. 2011. "Bruton Vows to Defend Rate of Corporate Tax 'Tooth and Nail'." The Irish Times (16 April). http://www.irishtimes.com/newspaper/ireland/2011/0416/1224294802052.html Accessed April 16, 2011.

Department of Finance. 1958a. Economic Development. Dublin: Stationery Office.

-----. 1958b. First Programme for Economic Expansion. Dublin: Stationery Office.

-----. 1963. Second Programme for Economic Expansion (Part 1). Dublin: Stationery Office.

-----. 1964. Second Programme for Economic Expansion (Part 2). Dublin: Stationery Office.

Donnelly, Paul F. 2007. Organizational Forming in Amodern Times: Path Dependence, Actor Network Theory, and Ireland's Industrial Development Authority. Unpublished diss, University of Massachusetts, Amherst.

Dullforce, William. 1982a. "Fears for the Welfare State.” Financial Times (18 September): 15.

-----. 1982b. “Sweden Raises Taxes in 'Crisis’ Economic Plan”, Financial Times (12 October): 1.

European Commission. 1997. Eurostat Yearbook. Luxembourg: Office for Official Publications of the European Communities.

European Commission. 2003. Eurostat Yearbook. Luxembourg: Office for Official Publications of the European Communities.

Feldstein, Martin. 1994. American Economic Policy in the 1980s. Chicago, IL: University of Chicago Press.

FitzGerald, Garrett. 1959. “Population Prospects.” The Irish Times (27 May): 5.

Garrett, Geoffrey, and Peter Lange. 1995. "Internationalization, Institutions, and Political Change." International Organization 49 (4): 627-55. 
Garuba, Dauda S. 2006. "Survival at the Margins: Economic Crisis and Coping Mechanisms in Rural Nigeria." Local Environment 11 (1): 17-36.

Garvin, Tom. 1982. The Evolution of Irish Nationalist Politics. Dublin: Gill and Macmillan.

Gerring, John. 2007. Case Study Research: Principles and Practices. Cambridge: Cambridge University Press.

Geva-May, Iris. 2004. "Riding the Wave of Opportunity: Termination in Public Policy." Journal of Public Administration Research and Theory 14 (3): 309-33.

Girvin, Brian. 1994. "Trade Unions and Economic Development.” In Trade Union Century, ed. Donal Nevin. Cork: Mercier Press, 117-32.

Golob, Stephanie R. 2003. "Beyond the Policy Frontier: Canada, Mexico, and the Ideological Origins of NAFTA.” World Politics 55 (3): 361-98.

Greener, Ian. 2001. "Social Learning and Macroeconomic Policy in Britain.” Journal of Public Policy 21 (2): 133-52.

Haas, Peter M. 2004. "When Does Power Listen to Truth? A Constructivist Approach to the Policy Process." Journal of European Public Policy 11 (4): 569-92.

Hacker, Jacob. S. 2005. "Policy Drift: The Hidden Politics of US Welfare State Retrenchment." In Beyond Continuity. Institutional Change in Advanced Political Economies, eds. Wolfgang Steeck and Kathleen Thelen. Oxford: Oxford University Press, 40-82.

Haggard, Stephan. 1988. "The Institutional Foundations of Hegemony: Explaining the Reciprocal Trade Agreements Act of 1934.” International Organization 42 (1): 91-119.

-----, and Robert. R. Kaufman. 1995. The Political Economy of Democratic Transitions. Princeton, NJ: Princeton University Press.

Hall, Peter A. 1993. "Policy Paradigms, Social Learning, and the State: The Case of Economic Policy Making in Britain." Comparative Politics 25 (3): 275-96.

Haughton, Jonathan. 1995. "The Historical Background." In The Economy of Ireland: Policy and Performance of a Small European Country, ed. John W. O’Hagan. Dublin: Gill and Macmillan, 1-49.

Heston, Alan, Robert Summers, and Bettina Aten. 2002. Penn World Table Version 6.1. Philadelphia, PA: Center for International Comparisons of Production, Income and Prices at the University of Pennsylvania.

Hillery, Brian. 1980. "Industrial Relations: Compromise and Conflict.” In Trade Unions and Change in Irish Society, ed. Donal Nevin. Dublin: Mercier Press, 39-52.

Hogan, John. 2006. "Remoulding the Critical Junctures Approach." Canadian Journal of Political Science 39 (3): 657-79. 
-----, and David Doyle. 2007. "The Importance of Ideas: An A Priori Critical Juncture Framework." Canadian Journal of Political Science 40 (4): 883-910.

Horgan, John. 1997. Seán Lemass: The Enigmatic Patriot. Dublin: Gill and Macmillan.

Howlett, Michael. 2007. "Re-Visiting the New Orthodoxy of Policy Dynamics: The Dependent Variable and Re-Aggregation Problems in the Study of Policy Change." Canadian Political Science Review 1 (2): 50-62.

-----. 2009. "Process Sequencing Policy Dynamics: Beyond Homeostasis and Path Dependency." Journal of Public Policy 29 (3): 241-62.

-----, and Benjamin Cashore. 2009. "The Dependent Variable Problem in the Study of Policy Change: Understanding Policy Change as a Methodological Problem." Journal of Comparative Policy Analysis: Research and Practice 11 (1): 33-46.

Hwang, Hokyu, and Walter Powell. 2005. "Institutions and Entrepreneurship." In Handbook of Entrepreneurship Research: Disciplinary Perspectives, eds. Sharon A. Alvarez, Rajshree R. Agarwal, and Olav Sorenson. New York, NY: Springer, 201-32.

Irish Independent. 1958a. "Economic Isolation Impracticable”, (11 March): 11.

-----. 1958b. "Free Trade Area Conference”, (22 February): 10.

-----. 1959a. "Productivity Must Be Doubled", (28 September): 4.

-----. 1959b. “Dáil Elects New Taoiseach”, (24 June): 9.

Jones, Bryan D., and Frank R. Baumgartner. 2005. The Politics of Attention: How Government Prioritizes Problems. Chicago, IL: University of Chicago Press.

Jones, Michael D., and Hank C. Jenkins-Smith. 2009. "Trans-Subsystem Dynamics: Policy Topography, Mass Opinion, and Policy Change.” Policy Studies Journal 37 (1): 37-58.

Kaminsky, Graciela L., Carmen M. Reinhart, and Carlos A. Végh. 2003. "The Unholy Trinity of Financial Contagion.” Journal of Economic Perspectives 17 (4): 51-74.

Kingdon, John W. 1995. Agendas, Alternatives, and Public Policy, $2^{\text {nd }}$ ed. New York, NY: Harper.

Kleistra, Yvonne, and Igor Mayer. 2001. "Stability and Flux in Foreign Affairs: Modelling Policy and Organizational Change." Cooperation and Conflict 36 (4): 381-414.

Krippendorff, Klaus. 2004. Content Analysis: An Introduction to Its Methodology, $2^{\text {nd }}$ ed. Beverly Hills, CA: Sage.

Kwon, Soonman. 2001. "Economic Crisis and Social Policy Reform in Korea." International Journal of Social Welfare 10 (2): 97-106. 
Leddin, Anthony J., and Brendan M. Walsh. 1998. The Macroeconomy of Ireland, $4^{\text {th }}$ ed. Dublin: Gill and Macmillan.

Lee, Joseph J. 1989. Ireland, 1912-1985: Politics and Society. Cambridge: Cambridge University Press.

Legro, Jeffrey W. 2000. "The Transformation of Policy Ideas.” American Journal of Political Science 44 (3): 419-32.

Lieberman, Evan. S. 2001. "Causal Inference in Historical Institutional Analysis: A Specification of Periodization Strategies.” Comparative Political Studies 34 (9): 1011-35.

Lijphart, Arend. 1999. Patterns of Democracy: Government Forms and Performance in Thirty-six Countries. New Haven, CT: Yale University Press.

Lynch, Patrick. 1959. “The Economics of Independence.” The Irish Times (27 May): 7.

Lyons, Francis S. L. 1973. Ireland Since the Famine. London: Fontana.

Mahoney, James. 2001. "Path Dependent Explanations of Regime Change: Central America in Comparative Perspective." Studies in Comparative International Development 36 (1): 111-41.

-----, and Dietrich Rueschemeyer. 2003. "Comparative Historical Analysis: Achievements and Agendas." In Comparative Historical Analysis in the Social Sciences, eds. James Mahoney and Dietrich Rueschemeyer. Cambridge: Cambridge University Press, 3-40.

Maxwell, Joseph A. 2005. Qualitative Research Design: An Interactive Approach. $2^{\text {nd }}$ ed. London: Sage.

Meidner, Rudolf. 1989. "The Swedish Labour Movement at the Crossroads." Studies in Political Economy 28 (1): 7-31.

-----. 1993. “Why Did the Swedish Model Fail?” The Socialist Register 29: 211-28.

Meijerink, Sander. 2005. "Understanding Policy Stability and Change: The Interplay of Advocacy Coalitions and Epistemic Communities, Windows of Opportunity, and Dutch Coastal Flooding Policy 1945-2003.” Journal of European Public Policy 12 (6): 1060-77.

Mintrom, Michael. 2000. Policy Entrepreneurs and School Choice. Washington, DC: Georgetown University Press.

-----, and Phillipa Norman. 2009. "Policy Entrepreneurship and Policy Change." Policy Studies Journal 37 (4): 649-67.

Mitchell, Brian R. 1992. International Historical Statistics, Europe 1750-1988, $3^{\text {rd }}$ ed. New York, NY: Stockton Press.

Mjoset, Lars. 1992. The Irish Economy in a Comparative Institutional Perspective. Dublin: National Economic and Social Council. 
Murphy, Gary. 1997. "Government, Interest Groups and the Irish Move to Europe." Irish Studies in International Affairs 8: 57-68.

-----. 2005. "From Economic Nationalism to European Union." In The Lemass Era: Politics and Society in the Ireland of Seán Lemass, eds. Brian Girvin and Gary Murphy. Dublin: University College Dublin Press, 28-48.

Nohrstedt, Daniel. 2005. "External Shocks and Policy Change: Three Mile Island and Swedish Nuclear Energy Policy." Journal of European Public Policy 12 (6): 1041-59.

-----, and Christopher Weible. 2010. "The Logic of Policy Change After Crisis: Proximity and Subsystem Interaction," Risk, Hazards \& Crisis in Public Policy: 1 (2): 1-32.

O’Day, Alan. 2000. "Nationalism and Economic Question in Twentieth Century Ireland." In Economic Change and the National Question in Twentieth Century Europe, eds. Alice Teichova, Herbert Matis, and Jaroslav Pátek. Cambridge: Cambridge University Press, 9-32.

Ó Gráda, Cormac, and Kevin O’Rourke. 1995. "Economic Growth: Performance and Explanations." In The Economy of Ireland: Policy and Performance of a Small European Country, ed. John W. O'Hagan. Dublin: Gill and Macmillan, 198-227.

O'Hearn, Denis. 1998. Inside the Celtic Tiger: The Irish Economy and the Asian Model. London: Pluto Press.

Oliver, Michael J., and Hugh Pemberton. 2004. "Learning and Change in 20th-Century British Economic Policy.” Governance 17 (3): 415-41.

Organisation for Economic Cooperation and Development (OECD). 1961. Ireland 1961. Paris: OECD.

----. 1978. Sweden 1978. Paris: OECD.

-----. 1982. Sweden 1982. Paris: OECD.

-----. 1984. Sweden 1984. Paris: OECD.

----- 1990. Sweden 1990. Paris: OECD.

-----. 1992. Sweden 1992. Paris: OECD.

-----. 1995. Labour Force Statistics. OECD: Paris.

Organisation for European Economic Cooperation (OEEC). 1958. Ireland 1958. Paris: OEEC.

Osnos, Peter. 1982. "Palme to Push World Role for Sweden." The Washington Post (21 September): A15.

Pei, Minxin, and Ariel D. Adesnik. 2000. "Why Recessions Don’t Start Revolution.” Foreign Policy 118 (1): 138-51. 
Pemberton, Hugh. 2000. "Policy Networks and Policy Learning: UK Economic Policy in the 1960s and 1970s.” Public Administration 78 (4): 771-92.

Peterson, Richard B. 1987. "Swedish Collective Bargaining - A Changing Scene." British Journal of Industrial Relations 25 (1): 31-48.

Pierson, Paul. 1993. "When Effect Becomes Cause: Policy Feedback and Political Change." World Politics 45: 595-628.

Polgar, Stephen and Shane A. Thomas. 2008. Introduction to Research in the Health Sciences. $5^{\text {th }}$ ed. Edinburgh: Churchill Livingstone.

Robinson, Scott E. 2007. "Punctuated Equilibrium Models in Organizational Decision Making." In Handbook of Decision Making, ed. Göktuğ Morçöl. New York, NY: CRC Taylor and Francis, 133-49.

Ryden, Bengt, and Villy Bergstrom. 1982. "Sweden in the 1980s: How Gloomy Are the Prospects?" In Sweden: Choices for Economic and Social Policy in the 1980s, eds. Bengt Ryden and Villy Bergstrom. London: Allen and Unwin, 1-8.

Sabatier, Paul A. 1988. "An Advocacy Coalition Framework of Policy Change and the Role of PolicyOriented Learning Therein.” Policy Sciences 21 (2/3): 129-68.

-----, and Chris Weible. 2007. "The Advocacy Coalition: Innovations and Clarifications." In Theories of the Policy Process, $2^{\text {nd }}$ ed., ed. Paul Sabatier. Boulder, CO: Westview Press, 189-220.

Sheingate, Adam D. 2003. "Political Entrepreneurship, Institutional Change, and American Political Development." Studies in American Political Development 17 (2): 185-203.

Skocpol, Theda. 1979. States and Social Revolutions: A Comparative Analysis of France, Russia and China. Cambridge: Cambridge University Press.

Stone, Deborah A. 1989. "Causal Stories and the Formation of Policy Agendas." Political Science Quarterly 104 (2): 281-300.

Streeck, Wolfgang, and Kathleen Thelen. 2005. "Introduction: Institutional Change in Advanced Political Economies." In Beyond Continuity. Institutional Change in Advanced Political Economies, eds. Wolfgang Steeck and Kathleen Thelen. Oxford: Oxford University Press, 1-39.

The Economist. 1959. “Mr. Lemass’s Inheritance.” (4 July): 15.

The Irish Times. 1957a. "Employment the Theme of Election Speeches.” (23 February): 1.

----. 1957b. "Unemployment is the Enemy.” (15 March): 9.

----. 1959a. “Portrait Gallery: Seán F. Lemass.” (27 June): 8.

-----. 1959b. “Two Obstacles to Economic Development.” (2 May): 9. 
-----. 2011. "Value of Irish Exports Tops €161 Billion". (5 January). http://www.irishtimes.com/newspaper/breaking/2011/0105/breaking23.html/. Accessed 16 April, 2011.

Thelen, Kathleen. 2004. How Institutions Evolve: The Political Economy of Skills in Germany, Britain, the United States and Japan. Cambridge: Cambridge University Press.

Tilly, Charles. 1975. The Formation of Nation States in Western Europe. Princeton, NJ: Princeton University Press.

Time International. 1958. "Welcome to Ireland.” (31 March): 44.

-----. 1976. "Sweden: Social Democrats: 44 and Out." (4 October): 8.

-----. 1982. “Sweden: Palme’s Sunday.” (4 October): 23.

United Nations. 2011. United Nations Data: A World of Information. http://data.un.org/Data.aspx?d=IFS\&f=SeriesCode\%3a60. Accessed 10 September, 2011.

Walters, Peter. 1987. "The Legacy of Olof Palme: The Condition of the Swedish Model." Government and Opposition 22 (1): 64-77.

Whyman, Philip, and Brian Burkitt. 1993. "The Role of the Swedish Employers in Restructuring Pay Bargaining and the Labour Process." Work, Employment \& Society 7 (4): 603-14.

Zittoun, Philippe. 2009. "Understanding Policy Change as a Discursive Problem." Journal of Comparative Policy Analysis: Research and Practice 11 (1): 65-82. 
Figure 1 - Policy Change Pyramid

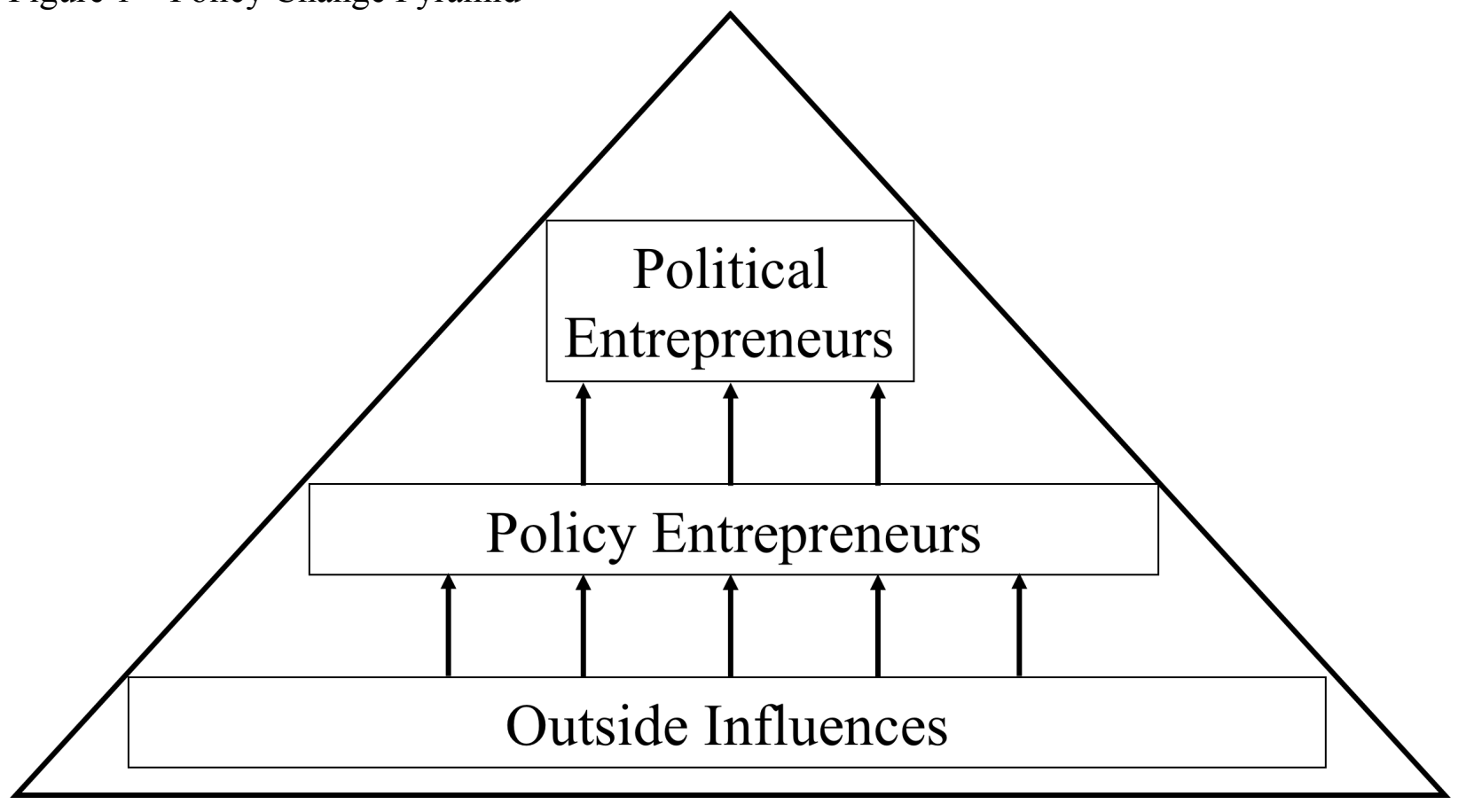

Table 1 - Ireland's Main Economic Indicators, 1950-1964

\begin{tabular}{|c|c|c|c|c|c|c|}
\hline Year & $\begin{array}{c}\text { Unemployment } \\
\%\end{array}$ & $\begin{array}{c}\text { Inflation } \\
\%\end{array}$ & $\begin{array}{c}\text { Interest } \\
\%\end{array}$ & $\begin{array}{c}\text { Government } \\
\text { Debt to GNP } \\
\text { ratio }\end{array}$ & $\begin{array}{c}\text { Growth Rates in } \\
\text { Real GDP } \\
\%\end{array}$ & $\begin{array}{c}\text { Economic } \\
\text { Openness }^{5}\end{array}$ \\
\hline 1950 & 7.5 & 0.0 & 2.5 & N/A & 1.9 & 70.9 \\
\hline 1951 & 7.3 & 11.3 & 2.5 & 49.9 & 1.9 & 82.6 \\
\hline 1952 & 9.1 & 10.1 & 3.5 & N/A & 2.3 & 69.6 \\
\hline 1953 & 9.6 & 2.0 & 3.5 & N/A & 2.5 & 66.9 \\
\hline 1954 & 8.1 & 2.0 & 3.0 & N/A & 0.9 & 65.5 \\
\hline 1955 & 6.8 & 1.9 & 4.0 & N/A & 1.9 & 67.2 \\
\hline 1956 & 7.7 & 4.4 & 5.0 & N/A & -1.5 & 63.9 \\
\hline 1957 & 9.2 & 2.6 & 6.0 & N/A & 1.0 & 62.7 \\
\hline 1958 & 8.6 & 2.6 & 4.3 & N/A & -2.2 & 62.9 \\
\hline 1959 & 8.0 & -0.9 & 4.3 & 55.5 & 4.1 & 62.7 \\
\hline 1960 & 6.7 & 0.9 & 4.6 & 57.5 & 5.0 & 64.7 \\
\hline 1961 & 5.0 & 2.8 & 5.6 & 57.8 & 3.2 & 69.8 \\
\hline 1962 & 4.8 & 4.3 & 3.9 & 58.3 & 3.1 & 66.8 \\
\hline 1963 & 5.0 & 2.5 & 4.0 & 58.9 & 4.7 & 69.9 \\
\hline 1964 & 4.7 & 6.7 & 6.8 & 55.2 & 3.8 & 70.1 \\
\hline
\end{tabular}

Sources: European Commission (1997); Heston, Summers, and Aten (2002); Leddin and Walsh (1998); Mitchell (1992); United Nations (2011).

\footnotetext{
${ }^{5}$ Measured by the trade to GDP ratio. This is acquired by adding the value of imports and exports and dividing by GDP.
} 
Table 2 - Sweden's Main Economic Indicators, 1973-1987

\begin{tabular}{|c|c|c|c|c|c|c|}
\hline Year & $\begin{array}{c}\text { Unemployment } \\
\%\end{array}$ & $\begin{array}{c}\text { Inflation } \\
\%\end{array}$ & $\begin{array}{c}\text { Interest } \\
\%\end{array}$ & $\begin{array}{c}\text { Government } \\
\text { Debt to GNP } \\
\text { ratio }\end{array}$ & $\begin{array}{c}\text { Growth Rates in } \\
\text { Real GDP } \\
\%\end{array}$ & $\begin{array}{c}\text { Economic } \\
\text { Openness }^{6}\end{array}$ \\
\hline 1973 & 2.5 & 6.7 & 5.5 & 22.6 & 3.9 & 50.9 \\
\hline 1974 & 2.0 & 9.9 & 7.5 & 24.2 & 4.3 & 63.7 \\
\hline 1975 & 1.6 & 9.8 & 6.5 & 24.4 & 2.2 & 55.2 \\
\hline 1976 & 1.6 & 10.3 & 8.5 & 23.6 & 1.2 & 55.7 \\
\hline 1977 & 1.8 & 11.4 & 8.5 & 26.5 & -2.0 & 55.2 \\
\hline 1978 & 2.2 & 10.0 & 7.0 & 31.8 & 1.3 & 54.2 \\
\hline 1979 & 2.1 & 7.2 & 9.5 & 37.9 & 4.3 & 60.4 \\
\hline 1980 & 2.0 & 13.7 & 11.3 & 43.2 & 1.9 & 60.1 \\
\hline 1981 & 2.5 & 12.1 & 11.8 & 50.8 & -0.6 & 59.6 \\
\hline 1982 & 3.1 & 8.6 & 11.3 & 59.3 & 1.1 & 64.9 \\
\hline 1983 & 3.5 & 9.0 & 9.8 & 64.6 & 1.8 & 68.9 \\
\hline 1984 & 3.1 & 8.0 & 10.8 & 67.1 & 4.0 & 68.8 \\
\hline 1985 & 2.8 & 7.4 & 12.0 & 68.7 & 1.9 & 68.5 \\
\hline 1986 & 2.7 & 4.2 & 9.0 & 66.6 & 2.3 & 62.2 \\
\hline 1987 & 1.9 & 4.2 & 8.8 & 60.8 & 3.1 & 62.7 \\
\hline
\end{tabular}

Sources: European Commission (1997, 2003); Heston, Summers, and Aten (2002); Mitchell (1992); OECD (1995); United Nations (2011).

Table 3 - Identification of Macroeconomic Crisis

\begin{tabular}{|l|c|c|}
\hline Identification of Macroeconomic Crisis & $\begin{array}{c}\text { Ireland } \\
\text { late 1950s }\end{array}$ & $\begin{array}{c}\text { Sweden } \\
\text { early 1980s }\end{array}$ \\
\hline O1. Stagnant or negative GDP growth & 3 & 3 \\
O2. Unemployment above 10 percent & 2 & 1 \\
O3. Inflation and interest rates above 10 percent & 1 & 3 \\
O4. National debt, as a percentage of GDP, increasing at more & 1 & 3 \\
than 10 percent, annually & 3 & 1 \\
O5. The level of economic openness declining & $\mathrm{N} / \mathrm{A}$ & 2 \\
O6. Public perceives economic crisis & 3 & 3 \\
O7. Media perceive economic crisis & 3 & 3 \\
O8. Economic/political commentators perceive economic crisis & 3 & 3 \\
O9. Central bank perceives economic crisis & 3 & 3 \\
O10. OECD perceives economic crisis & 3 & 2 \\
O11. Elected representatives perceive economic crisis & 3 & 2 \\
O12. Government pronouncements consistent with crisis & & Strong \\
\hline \hline
\end{tabular}

(3) strong support | (2) medium support | (1) weak support | (0) no support | (N/A) not available

\footnotetext{
${ }^{6}$ Measured by the trade to GDP ratio. This is acquired by adding the value of imports and exports and dividing by GDP.
} 
Table 4 - Indication of: (i) Ideational Collapse; (ii) New Ideational Consolidation; (iii) Level of Policy Change

\begin{tabular}{|c|c|c|}
\hline (i) Indication of Extant Ideational Collapse & $\begin{array}{c}\text { Ireland } \\
\text { late } 1950 \mathrm{~s}\end{array}$ & $\begin{array}{c}\text { Sweden } \\
\text { early } 1980 \mathrm{~s}\end{array}$ \\
\hline O13. Media questioning efficacy of current model & 3 & 3 \\
\hline $\begin{array}{l}\text { O14. Opposition critiques current model and propose alternative } \\
\text { ideas }\end{array}$ & 3 & 1 \\
\hline $\begin{array}{l}\text { O15. Policy entrepreneurs critique current model and propose } \\
\text { alternatives }\end{array}$ & 3 & 2 \\
\hline O16. Civil society organizations critique current model & 3 & 2 \\
\hline 017. Widespread public dissatisfaction with current paradigm & $\mathrm{N} / \mathrm{A}$ & 1 \\
\hline $\begin{array}{l}\text { O18. External/international organizations critique current model } \\
\text { and actively disseminate alternatives }\end{array}$ & 3 & 2 \\
\hline Extant Ideational Collapse & Strong & Medium \\
\hline (ii) Indication of New Ideational Consolidation & & \\
\hline 019. Clear set of alternative ideas & 3 & 1 \\
\hline O20. Political entrepreneur injecting new ideas into policy arena & 3 & 0 \\
\hline $\begin{array}{l}\text { O21. Political entrepreneur combines interests to produce } \\
\text { consensus around a replacement paradigm }\end{array}$ & 3 & 0 \\
\hline New Ideational Consolidation & Strong & No \\
\hline (iii) Indication of Level of Policy Change & & \\
\hline O22. Policy instrument settings changed & 3 & 3 \\
\hline O23. Instruments of policy changed & 3 & 1 \\
\hline O24. Goals behind policy changed & 3 & 0 \\
\hline Critical Juncture in Policy & Strong & No \\
\hline
\end{tabular}

(3) strong support | (2) medium support | (1) weak support | (0) no support | (N/A) not available 


\section{Appendix}

Inter-coder agreement scores

\begin{tabular}{|l|c|c|c|c|}
\hline & \multicolumn{2}{|c|}{ Ireland } & \multicolumn{2}{c|}{ Sweden } \\
\hline Crisis & Krippendorff's $\alpha$ & $\%$ Agreement & Krippendorff's $\alpha$ & $\%$ Agreement \\
\hline $\begin{array}{l}\text { Ideational } \\
\text { Collapse }\end{array}$ & 0.836 & $91 \%$ & 0.862 & $92 \%$ \\
\hline $\begin{array}{l}\text { Ideational } \\
\text { Consolidation }\end{array}$ & 1 & $100 \%$ & 1 & $100 \%$ \\
\hline Policy Change & $*$ & $100 \%$ & 1 & $100 \%$ \\
\hline
\end{tabular}

* Both coders attained 100 per cent agreement and both selected the same value for each observable. Under this invariant values scenario, Krippendorff's alpha is undefined. 